and montmorillonitic material was checked by X-ray diffraction. No stratification or organic structures could be observed in the thin sections.

\section{Sample 13-123-8-1, $98 \mathrm{~cm}$ - Volcanic Ash}

The sample is composed of coarse ash formed by acidic glass shards and pumice (up to $1.6 \mathrm{~mm}$ long) and angular fragments (up to $0.3 \mathrm{~mm}$ long) of volcanic minerals (plagioclase, sanidine and a few unidentified grains); all are cemented by dolomite or ankerite, opal, and some montmorillonitic material.

The presence of dolomite or ankerite, sanidine, plagioclase, opal, and montmorillonitic material was checked by $\mathrm{X}$-ray diffraction.

Lenticular layering is emphasized by an opaque material probably formed by a clay mineral (montmorillonite?) along with $\mathrm{Fe}-\mathrm{Mn}$ oxides. No organic structures were observed.

\section{Sample 13-123-8-1, $120 \mathrm{~cm}$ - Volcanic Ash}

The sample is composed of a coarse ash layer formed of acid glass shards and pumice (up to $5 \mathrm{~mm}$ long), and a few angular fragments and rounded phenocrysts (up to $1.2 \mathrm{~mm}$ long) of igneous minerals (sanidine, plagioclase, and micropegmatite); all are cemented by dolomite-ankerite, opal, and montmorillonitic material. The presence of dolomite or ankerite, plagioclase, sanidine, opal, and montmorillonitic material was checked by X-ray diffraction. Neither stratification nor organic structures was observed.

\section{Comments on the Site 123 - Volcanic Ash Layers}

The four ash layers studied by petrographic microscopy and X-ray diffraction seem to be closely related to the same volcanic source. This could be some explosive volcano(es) generating trachytic or latitic ash and pumice. Taking into account the explosiveness of such volcanoes, it is very difficult to estimate, with only one core, how far the craters were from Site 123. Nevertheless, the large fragments of pumice, the great thickness of the volcanic unit, and the welded nature of some of the levels all suggest a rather local source; perhaps the very same basement high on which the site is located.

\title{
28.2. CHEMISTRY OF THE VALENCIA TROUGH VOLCANIC ROCKS
}

\author{
M. Weibel and K. J. Hsü Geologisches Institute, Eidg. Technische Hochschule, Zurich, Switzerland
}

Two samples of volcanic rocks from the gravel in Hole 122 and one ash sample from Hole 123 were analyzed, using the improved rapid wet-chemical method devised by Weibel (1961). The results are shown in Table 1.

Unfortunately, the samples were so small that sections could not be made before the samples were pulverized for chemical analyses. Apparently, all the samples have undergone secondary alteration. Therefore, the water content is very high, from 5.7 to 8.8 per cent. Also noteworthy is the unusually low magnesium content, and rather high alkali content.

Results of the chemical analyses show that the samples from Hole 122 are basalt and that the sample from Hole 123 is dacite.

Cenozoic extrusive rocks are common in southern and eastern Spain, in Almeria (Cabo de Gata), Cartagena, Ciudad Real (Campos de Calatrava), Murcia, Cofrentes, Tarragona, Gerona, Isla de Alboran, Islas de Columbretes, etc. (Figure 1). Those occurrences were investigated by Osann $(1889,1891$ a,b), by Burri and Parga-Pondal (1933, $1935,1936,1937)$, and by others. Two volcanic provinces have been recognized:

(1) "Pacific Suite" in the Betic Cordillera Province. The volcanic rocks there include hypersthene basalts (on Isla de Alboran), andesites, and dacites.
(2) "Atlantic Suite" in the Iberian Foreland Province. These include mainly olivine basalts, nephelinite, and ankaratrites.

Also listed in Table 1 are the chemical analyses of these Spanish volcanics. Columns 4 to 7 give the composition of dacite, andesite, and basalts from the Betic Cordillera, and columns 8 and 9 show the composition of the Iberian Foreland rocks. The rocks from the Valencia Trough obviously belong to the first group.

Of particular interest is the eruptive series in Cabo de Gata described by Ossan in (1891 a,b). There he recognized a series of andesites and dacites older than the Pliocene limestone and demonstrated that these rocks are the product of subaerial volcanism. This volcanic formation is correlative to the cacitic tuff we sampled from Hole 123 . Osann (1891b) gave several analyses of the dacite from his area, one of which is shown in column 7, Table 1. A comparison shows that our dacite is richer in $\mathrm{H}_{2} \mathrm{O}$ and poorer in alumina and iron oxide (Cf. Columns 3 and 7, Table 1).

Genetically related to the Cabo de Gata volcanics are the hypersthene basalts on the Island of Alboran (Burri and Parg-Pondal, 1937, p. 262). These basalts were named hypersthene andesites or "alboranites" by Becke (1899) because they have a composition range between that of a 
TABLE 1

Chemical Analyses of Volcanic Rocks from Valencia Trough and Spain

\begin{tabular}{|c|c|c|c|c|c|c|c|c|c|}
\hline & 1 & 2 & 3 & 4 & 5 & 6 & 7 & 8 & 9 \\
\hline $\mathrm{SiO}_{2}$ & 50.1 & 49.9 & 63.5 & 52.28 & 56.32 & 61.08 & 62.21 & 64.78 & 40.03 \\
\hline $\mathrm{Al}_{2} \mathrm{O}_{3}$ & 17.2 & 17.4 & 10.5 & 15.33 & 16.05 & 17.25 & 15.60 & 17.81 & 9.61 \\
\hline $\mathrm{Fe}_{2} \mathrm{O}_{3}$ & 6.65 & 6.25 & 1.25 & 3.03 & 3.68 & 3.16 & 5.26 & 2.91 & 2.90 \\
\hline $\mathrm{FeO}$ & 2.75 & 2.4 & 0.7 & 5.77 & 5.35 & 3.10 & 1.36 & 0.24 & 7.60 \\
\hline $\mathrm{MnO}$ & 0.08 & 0.07 & 0.06 & 0.06 & 0.10 & 0.06 & - & 0.10 & 0.19 \\
\hline $\mathrm{MgO}$ & 2.6 & 2.4 & 3.1 & 6.26 & 4.45 & 2.82 & 2.61 & 0.08 & 12.65 \\
\hline $\mathrm{CaO}$ & 6.2 & 5.9 & 4.2 & 11.44 & 9.25 & 3.14 & 6.55 & 0.54 & 13.18 \\
\hline $\mathrm{Na}_{2} \mathrm{O}$ & 3.6 & 3.8 & 3.2 & 1.71 & 2.35 & 1.75 & 2.50 & 8.28 & 2.53 \\
\hline $\mathrm{K}_{2} \mathrm{O}$ & 2.4 & 2.4 & 2.9 & 1.22 & 0.55 & 3.33 & 1.63 & 4.16 & 1.08 \\
\hline $\mathrm{H}_{2} \mathrm{O}^{+}$ & & & & 1.36 & 0.81 & 2.63 & & 0.22 & 2.45 \\
\hline $\mathrm{H}_{2} \mathrm{O}-$ & 5.7 & 7.2 & 8.8 & 0.78 & 0.40 & 0.05 & 2.25 & 0.13 & 1.33 \\
\hline $\mathrm{TiO}_{2}$ & 1.98 & 1.76 & 0.15 & 0.77 & 0.48 & 0.79 & - & 0.44 & 5.79 \\
\hline $\mathrm{P}_{2} \mathrm{O}_{5}$ & 0.64 & 0.58 & 0.07 & 0.28 & 0.22 & 0.12 & - & 0.12 & 0.95 \\
\hline Others & - & - & - & - & - & 0.80 & - & - & - \\
\hline Total & 99.90 & 100.06 & 98.43 & 95.29 & 100.01 & 100.08 & 99.97 & 99.81 & 100.29 \\
\hline
\end{tabular}

Legend:

$\begin{array}{cl}\begin{array}{c}\text { Column } \\ 1\end{array} & \text { Basalt, DSDP Hole 122, Sample 13-122-4A-2, Analyst, M. Weibel. } \\ 2 & \text { Basalt, DSDP Hole 122, Sample 13-122-4A-B, Analyst, M. Weibel. } \\ 3 & \text { Dacite ash, DSDP Hole 123, Sample 13-123-8A, Analyst, M. Weibel. } \\ 4 & \text { Hypersthene basalt from Alboran, from Burri and Parga-Pondal, } 1937 . \\ 5 & \text { Hypersthene basalt from Alboran, from Burri and Parga-Pondal, 1937. } \\ 6 & \text { Garnet-bearing cordierite-andesite from Alboran, Burri and Parga-Pondal, } 1936 . \\ 7 & \text { Dacite, Cabo de Gata, Almeria, Osann (1891b). } \\ 8 & \text { Trachyite, Gerona, Burri and Parga-Pondal, 1935. } \\ 9 & \text { Ankaratrite, Campos de Calatrava, Burri and Parga-Pondal, } 1933 .\end{array}$

typical andesite and that of a typical basalt. Burri and Parga-Pondal (1937) found a remarkable similarity between the "alboranites" and the basalt-andesite series of the Fuji-Bonin province of Japan. Such a similarity may be more than coincidental when we recognize that both the Alboran-Cabo de Gata and the Fuji-Bonin volcanic rocks were products of andesitic volcanism behind island arcs. The Valencia Trough basalts are chemically similar to the alboranites, but the former seemed to be poorer in silica and richer in $\mathrm{H}_{2} \mathrm{O}$.

Mineralogically and chemically the Valencia Trough volcanics had little in common with the volcanic suite of the Iberian Foreland Province.

\section{REFERENCES}

Becke, F., 1899. Die Hypersthene andesite der Insel Alboran, Tscher. Min. Petr. Mitt. 18, 525

Burri, C. and Parga-Pondal, I., 1933. Zur Petrographie der basischen Eruptivgesteine der Campos de Calatrava
(Provinz Ciudad Real, Spanien). Schweiz. Min. Petr. Mitt. 13, 40.

1935. Beiträge zur Kenntnis einiger jungvulkanischer Gesteine Spaniens. Schweiz. Min. Petr. Mitt. $15,266$.

—, 1936. Neue Beiträge zur Kenntnis des granatführenden Cordieritandesites vom Hoyazo bei Nijar (Provinz Almeria, Spanien). Schweiz. Min. Mitt. 16 226.

1937. Die Eruptivgesteine der Insel Alboran (Provinz Almeria, Spanien). Schweiz. Min. Petr. Mitt. 17, 230.

Osann, A., 1899. Beiträge zur Kenntniss der Eruptivgesteine der Cabo de Gata (Prov. Almeria). Z. Deutsch. Geol. Gesell., 41, 297. 1891a. Ueber den geologischen Bau des Cabo de Gata. Z. Deutsch. Geol. Gesell., 43, 323.

, 1891. Beiträge zur Kenntniss der Eruptivgesteine des Cabo de Gata. I. Z. Deutsch. Geol. Gésell. 43, 688.

Weibel, M., 1961. Die Schnellmethoden der Gesteinanalyse. Schweiz. Min. Petr. Mitt., 41, 285. 


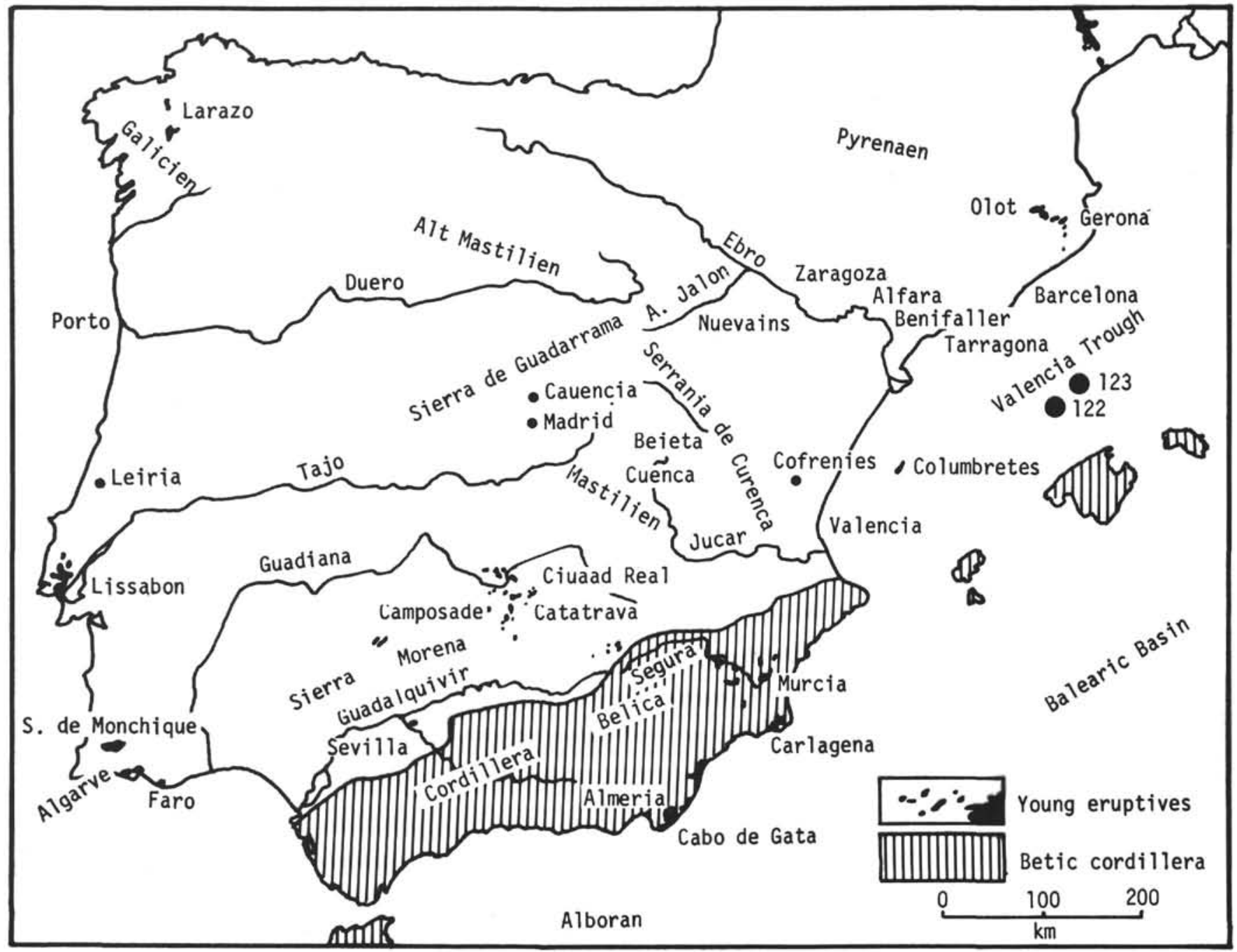

Figure 1. Distribution of volcanic rocks of Cenozoic age in Spain and Portugal and the locations of Sites 122 and 123 in the Valencia Trough. (After Burri and Parga-Pondal, 1935).

\subsection{TRACE ELEMENTS IN THE VALENCIA TROUGH VOLCANIC ROCKS}

J. R. Cann, School of Environmental Sciences, University of East Anglia, Norwich, England and

K. J. Hsü, Geologisches Institute, Eidg. Technische Hochschule, Zurich, Switzerland

Three samples of the Valencia Trough volcanics were analysed for $\mathrm{Rb}, \mathrm{Sr}, \mathrm{Y}, \mathrm{Zr}$, and $\mathrm{Nb}$. These samples were the pulverized powders from Weibel after his wet-chemical analyses. One of the samples contained too little material to yield any meaningful data. The results of the other two analyses are shown in Table 1.

Sample 13-122-4A-2 shows strong affinities to alkali basalt; our present stage of knowledge does not yet permit us to determine if such an alkali basalt is continental or marine. Sample 13-123-8-CC, being a dacite, cannot yet be typed on the basis of trace-element analysis. Obviously, considerably more investigation will be needed before definitive conclusions can be drawn. Nevertheless, it is noteworthy that neither of the rocks analysed show any affinity in their trace-element composition to the ocean-floor basalts. 